Journal homepage: http://www.journalijar.com

Journal DOI: $\underline{10.21474 / I J A R 01}$

RESEARCH ARTICLE
INTERNATIONAL JOURNAL

OF ADVANCED RESEARCH

"थ"थ"थ"थ"

ISSN NO. 2320-5407

\title{
STUDIES ON DIVERSITY AND SEASONAL VARIATION OF DIATOMS.
}

\author{
K. Rajyalaxmi and $* M$. Aruna.
}

Department of Botany, Telangana University, Dichpally, Nizamabad.(T.S.). India.

\section{Manuscript Info}

Manuscript History:

Received: 18 May 2016

Final Accepted: 22 June 2016

Published Online: July 2016

Key words:

Diversity, Bacillariophyceae, Lake.

*Corresponding Author

\begin{abstract}
The present study is to document the diversity and distribution of the fresh water Diatoms of a Lake located in Chandrugonda area of Khammam district Telangana state, South India. For the study of Bacillariophyceae biodiversity, the survey was conducted and samples were collected month wise from all selected sites of the Lake for a period of one year, November 2014 - October 2015. Altogether 20 Bacillariophycean members, popularly called as Diatoms were recorded from the study area.
\end{abstract}

\section{Aruna}

Copy Right, IJAR, 2016,. All rights reserved.

\section{Introduction:-}

Bacillariophyceae or Diatoms, a unique group of organisms is cosmopoliton, they grow in variety of habitats such as fresh water, wet sand and muddy areas. The members of Diatoms are unicellular and colonial aggregation form, the two major modes of existence of these species are benthic and planktonics. Benthic forms live upon substrata, like rocks, sand and are epiphytic. The planktonics are free-floating living near the surface of study site. The Diatoms form a major component of the planktonic vegetation. They serve as primary producers in the food web of aquatic ecosystem. Fresh water Diatom species have been studied by several workers such as Gonzaives (1947), Gandhi (1952), Venkataraman (1956), Pandey UC \& Pandey DC 1980 a , Sarode PT \& Kamat ND 1980 a. However the diatom diversity from lakes of khammam is unexplored. The present study includes systematic account of 20 species.

\section{Study area:-}

A lake situated in Chandrugonda area of khammam district is selected for assessment of biodiversity of Bacillariophycean members. The environmental conditions during study period are with a rainfall of $860 \mathrm{~mm}$, the average minimum temperature is $19^{\circ} \mathrm{C}$ in December and Maximum is $48^{0} \mathrm{C}$ in April-May. Based on the topography and geographical features (Table-I) of the study site it is confirmed that high temperatures and ph show positive significance for the growth of Diatom species.

Table 1:-

\begin{tabular}{|l|l|}
\hline Latitude & $17^{\circ} 23^{\prime} 0^{\prime \prime}$ \\
\hline Longitude & $17^{\circ} 23^{\prime} 0^{\prime \prime}$ \\
\hline Air Temperature & $19^{0} \mathrm{C}-48^{0} \mathrm{C}$ \\
\hline Water Temperature & $17^{0} \mathrm{C}-40^{0} \mathrm{C}$ \\
\hline Ph & $7.2-8.0$ \\
\hline Rainy season & June-September \\
\hline Average Rainfall & $860 \mathrm{~mm}$ \\
\hline
\end{tabular}

\section{Materials and methods:-}

Water samples were collected from different sites of the lake for the study of Bacillariophycean biodiversity. The survey was conducted and samples were collected month wise from all selected sites of th lake for a period of one year November 2014 to October, 2015,covering all localities like surface, bottom of the lake, lake canals, and lake 
surrounding crop fields. Collected samples were placed in centrifuge tube to remove carbonates and organic matter. After one week the samples were washed with distilled water, then placed in $50 \%$ alcohol and preserved in $4 \%$ formalin. Collected samples were stained and mounted on a slide and examined for identification by using Olympus Binocular Microscope. Identification of the taxa was done using Fritsch (1961), Prescott (1962), Gandhi (1956), Mohan (1980) and Krishnamurthy V (1954). The collections have been deposited in Phycology lab, Department of Botany, Telangana University, Nizamabad.

\section{Results and discussion:-}

The study revealed that the lake is eutrophic in nature and is dominated by Bacillariophyceae members (Table - II). However high species diversity was exhibited by the genera Navicula. Altogether $\mathbf{2 0}$ taxa were recorded from the study area, which were unicellular, and colonial aggregation forms and pseudo filamentous. The Genera Cyclotella and Melosira belong to Centrales, the cell exhibits radial symmetry. The Genera Achnanthes, Cymbella, Calonies, Gomphonema, Navicula, Nitzschia, Pinnularia and Synedra belong to Pennales which exhibits bilateral symmetry. The identified species occurred in water, on rocks, wood, mud area, few are epiphytic and endophytic. The Diatom species showed maximum count in summer and rainy seasons, minimum count in winter season. Dominant species were Cyclotella glomerata, Achnanthes lanceolata, Caloneis bacillaris, Cymbella cymbiformis, Gomphonema gracile, Navicula cuspida and Pinnularia gibba.

\section{Based on the species}

Navicula $>$ Cymbella $=$ Cyclotella $>$ Nitzschia $>$ Melosira $=$ Achnanthes $=$ Calonies $=$ Fragilaria $=$ Gamphonema $=$ Pinnularia = Synendra.

Table- 111:- enlists the Diatoms recorded in lake water showing seasonal variation

Table 2:-

\begin{tabular}{|l|l|l|l|}
\hline S.no & Family & Number of genera & Number of species \\
\hline 1 & Naviculaceae & 3 & 7 \\
\hline 2 & Coscinodiscineae & 2 & 4 \\
\hline 3 & Fragillariaceae & 2 & 2 \\
\hline 4 & Cymbellaceae & 1 & 3 \\
\hline 5 & Nitzschiaceae & 1 & 2 \\
\hline 6 & Achanthaceae & 1 & 1 \\
\hline 7 & Gomphonemataceae & 1 & 1 \\
\hline
\end{tabular}

Diatoms recorded in lake water showing seasonal variation

\begin{tabular}{|l|l|l|l|l|l|l|}
\hline S.No & Scientific Name & Order & Family & Winter & Summer & Rainy \\
\hline 1. & Cyclotella glomerata & Centrales & Coscinodiscineae & - & ++ & ++ \\
\hline 2. & $\begin{array}{l}\text { Cyclotella } \\
\text { meneghiniana }\end{array}$ & Centrales & Coscinodiscineae & + & + & + \\
\hline 3. & Cyclotella stelligera & Centrales & Coscinodiscineae & + & + & - \\
\hline 4. & Melosera granulata & Centrales & Coscinodiscineae & - & + & + \\
\hline 5. & Achnanthes lanceolata & Pennales & Achnanthaceae & + & + & ++ \\
\hline 6. & Caloneis bacillaris & Pennales & Naviculaceae & + & ++ & + \\
\hline 7. & Cymbella affinis & Pennales & Cymbellaceae. & + & + & + \\
\hline 8. & Cymbella cymbiformis & Pennales & Cymbellaceae & - & + \\
\hline 9. & Cymbella tumida & Pennales & Cymbellaceae & + & ++ & + \\
\hline 10. & Fragilaria virescens & Pennales & Fragillariaceae & + & - & + \\
\hline 11. & Gomphonema gracile & Pennales & Gomphonemataceae & + & + & + \\
\hline 12. & Navicula cuspida & Pennales & Naviculaceae & - & ++ & + \\
\hline 13. & Navicula exigua & Pennales & Naviculaceae & + & ++ & + \\
\hline 14. & Navicula mutida & Pennales & Naviculaceae & - & + & + \\
\hline 15. & Navicula rostellata & Pennales & Naviculaceae & + & + & + \\
\hline 16. & Navicula sculpta & Pennales & Naviculaceae & - & - & - \\
\hline 17. & Nitzschia acicularis & Pennales & Nitzschiaceae & + & + & + \\
\hline 18. & Nitzschia palea & Pennales & Nitzschiaceae & - & + & - \\
\hline 19. & Pinnularia gibba & Pennales & Naviculaceae & + & + & + \\
\hline 20. & Synedra ulna & Pennales & Fragillariaceae & - & + \\
\hline
\end{tabular}

Absent ; + Present ; ++ Dominant 


\section{Acknowledgement:-}

We express our deep sense of gratitude to Prof. VIDYAVATI, Former Vice-Chancellor of Kakatiya University, Warangal, Telangana State for her valuable suggestions and constant encouragement

\section{References:-}

1. APHA; 1976. Standard methods for the examination of water and waste water (14th Ed.). American Public Health Association, Washington. Pp. 1193.

2. APHA; 1985 Standard methods for the examination of water and waste water, $16^{\text {th }}$ American Public Water Works Association and Water Pollution Control Federation, New York.

3. Das, S.M. and Srivastava, V.K.; 1956. Quantitative studies on freshwater plankton and hydrobiological factors. Indian J. Ecology, 10(6): 40-55.

4. Gandhi HP; 1955 A contribution to our knowledge of the fresh water diatoms of Pratapgrah, Rajasthan, J India Bot soc 34 307-338.

5. Krishnamurthy V; 1954 A contribution to the diatom flora of South India. J India bot soc 33354 - 381.

6. Mohan, K.S.; 1980. Limnology of the Osman sagar and Mir Alam lakes. Ph.D.Thesis, Osmania University, Hyderabad, A.P.

7. Munawar, M.; 1970. Limnological studies on freshwater ponds of Hyderabad, India. II. The biocenose distribution of unicellular and colonial phytoplankton in Polluted and unpolluted environments. Hydrobiologia, 36: 105-128.

8. Pandey UC \& Pandey DC; 1980b Diatom flora of Allahabad (India I). Proc Indian Natn Sci Acad 46 (3) 350355.

9. Prescott, G.W.; 1962. Algae of the Western Great Lakes Area. 2nd ed. Wm. C. Brown Co., Dubuque, Iowa 977 pp.

10. Sarode PT \& Kamat N D; 1980a The Diatom flora of Nagpur India. Nova Hedwigia 32 797-838.

11. Smith G.M.; 1950. Fresh water Algae of United States. Mc Graw Hill Company New Yark Toronto London 719.

12. Venkataraman G; 1939 A systematic account of some south Indian Diatoms. Proc Indian Acad sci 10 (6) b 293-368.

13. Venkataraman G; 1956 Contribution to our knowledge of Freshwater Diatoms of South India. Govt Press Madras $20 \mathrm{pp}$.

14. Zafar, A.R.; 1964. On the ecology of algae in certain fish ponds of Hyderabad, India. Distribution of unicellular and colonial forms. Hydrobiologia, 24(4): 556-566. 